\title{
PENINGKATAN KECERDASAN SPIRITUAL MELALUI METODE ROLE PLAYINGUNTUK ANAK USIA DINI
}

\author{
Umi KultsumRiadul Badiah ${ }^{1}$, Dewi Safitri Elshap ${ }^{2}$ \\ ${ }^{1}$ RA AlbidayahCangkorah, Jln. Raya Batujajar No. 01 \\ ${ }^{2}$ IKIP Siliwangi,Jalan Terusan Jenderal Sudirman Cimahi \\ 1umikultsum302@gmail.com, ${ }^{2}$ dewielshap03@gmail.com
}

\begin{abstract}
The objective of this research was to understand comprehensively the effort to improving the spiritual student of RA Albidayah. The method that have been used in aim to improve spiritual quotient is role play. The data were collected trough participant using interview, observation and test. The data analysis and interpretation indicates that the role play method can be used to improv the spiritual student of RA Albidayah. The role play that have been use in this research have three stages which are preparation, execution, evaluation and discussion. The findings lead to the recommendation for the teacher to use the role play method in aim to improve the spiritual quotient in the RA Albidayah.
\end{abstract}

Keywords: spiritual quotient, role play method, action research

\begin{abstract}
Abstrak:sasaran inipengkajian tindakan ini yaitu untuk memahami secara komprehensif upaya dari meningkatnya kecerdasan anak RA Albidayah. Metode yang telah digunakan dalam penelitian ini yaitu untuk meningkatkan kecerdasan anak metode bermain peran. Data dikumpulkan melalui penggunaantes dan bercakap-cakap bersama anak didik. Analisin dan interpretasi data menunjukan bahwa cara ini mampudigunakan dalam meningkatkan kecerdasan anak di RA Albidayah. Permainan yang telah digunakan dalam penelitian ini, memiliki tiga tahap, yaitu persiapan, pelaksanaan, dan evaluasi. Diskusi temuan mengarah pada rekomendasi bagi guru untuk menggunakan cara pembelajaran dalam menstimulasi kecerdasan spiritual di RA Albidayah.
\end{abstract}

Kata kunci: kecerdasan jamak, cara penelitian, penelitian tindakan

\section{PENDAHULUAN}

Anak sebagai buah hati merupakan suatu titipandari Allah SWT yang diberikan kepada setiap manusia.Anak dilahirkan memiliki hal yang bersih dari berbagai pengaruh dengan keadaan yang lemah, dari segi rohani dan jasmani.Agar seorang anak memiliki kekuatan maka diperlukan penstimulusanagama yang cukup agar bisa membentengi si anak dari berbagai pengaruh, seperti lingkungan bermain saat berinteraksi dengan temannya.

Pendidikan untuk anak prasekolah merupakan tahapan pendidikan yang penting dalam rentang kehidupan manusia dan disebut juga anak yang

cepat tangkap mendapatkan pendidikan. Pengalaman yang di peroleh anak-anak dari lingkungan sekitar, dan pengaruh dari orang dewasa, akan berpengaruh bagi kehidupan anak-anak di waktu mendatang.

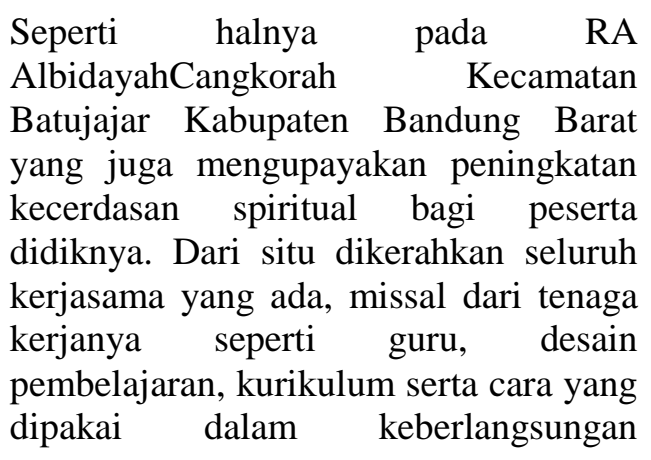


pembelajaran di RA tersebut. Pembelajaran dalam pendidikan anak usia dini dilakukan dengan cara bermain sambil belajar. Dalam situasi ini pendidik merencanakan pembelajaran dengan tujuan untuk membantu mengembangkan potensi anak-anak.

Untuk memperluas kecerdasan ini, pendidik biasanya mengajak anak untuk turun langsung kelapangan, danberpetualang, mengidentifikasi jenisjenis tanaman dan hewan di lingkungan sekitar dan sebagainya, serta menerangkan ciptaan-ciptan Tuhan yang indah, sehingga sebagai manusia wajib merawat sertamelestarikannya. Menurut peneliti, selain metode di atas, kecerdasan spiritual dapat pula dikembangkan melalui cara yang lain yaitu metode role playing. Cara ini berusaha membantu pada didik (anak usia dini) menemukan makna dari kehiduansosial lingkungan yang bermanfaat untuk dirinya. Bermain peran dapat membantu anak mengetahui aktor pemain peran dimainkan orang lain. Metode bermain peran akan mempermudah anak dalam mempelajari sesuatu, baik itu konsep keimanan, bahasa maupun pengetahuan lainnya. Anak akan merasa bahagia dengan apa yang dilakukannya. Apabila hal ini menjadi kegiatan inti dalam pembelajaran mereka akan semakin teratur mengontrol permainan, merasa nyaman dalam bermain peran. Semua ini membutuhkan wadah yang dapat mengerahkan kegiatan bermain anak sehingga lebih bermanfaat kepada pengembangan bakat minat dan keterampilannya.

Kecerdasan spiritual yaitubagian utama di kehidupan manusia. Dengan meningkatkan kecerdasan ini akan membuat manusia menjungjung tinggi nilai-nilai dan norma kehidupan. Peningkatan kecerdasan pada anak prasekolah mampu disebar luaskan melalui salah satu metode yaitu cara bermain peran. Metode role playingmerupakan cara pembelajaran yang digunakan di TK atau RA pada umumnya.

Berdasarkan latar belakang di atas dapat diidentifikasikan juga masalah dalam penelitian ini, yaitu: "Ingin mengetahui apakah metode role playing(bermain peran) berpengaruh terhadap kecerdasan spiritual?

Adapun rumusan masalahnya yaitu: "Bagaimanakah penerapan metode role playing(bermain peran) yang dapat meningkatkan kecerdasan spiritual pada anak prasekolah di RA AlbidayahCangkorahBatujajar? “

Tujuan dari penelitian ini yaitu, untuk mendeskripsikan bagaimana cara penerapan metode role playing(bermain peran) dalam proses peningkatan kecerdasan spiritual di RA AlbidayahCangkorahBatujajar dan untuk mendeskripsikan hasil dari penerapan metode role playing(bermain peran) terhadap kecerdasan spiritual di RA AlbidayahCangkorah

\section{KAJIAN TEORI}

\section{Konsep Peserta didik pra sekolah}

Menurut Undang-undang Nomor 20 tahun 2003 tentang Sistem Pendidikan Nasional Pasal 1 ayat 14 yang menyatakan bahwa: "Pendidikan anak usia dini adalah suatu upaya pembinaan yang ditujukan kepada anak sejak lahir sampai usia enam tahun yang dilakukan melalui pemberian rangsangan pendidikan untuk membantu pertumbuhan dan perkembangan jasmani dan rohani agar anak memiliki kesiapan dalam memasuki pendidikan lebih lanjut".

Dalam perkembangannya masyarakat telah menunjukankepeduliannya terhadap masalah pendidikan, yang sesuai dengan berbagai jenis layanan, kondisi serta kemampuan yang ada, 
dalam berbagai jenis jalurformal dan nonformal.

Pendidikan Anak prasekolah ialah suatu upaya pembinaan yang diberikan kepada anak usia dini sampai dengan usia enam tahun yang dilakukan melalui pemberian rangsangan pendidikan untuk membantu perkembangan jasmani serta rohani agar anak didik memiliki kesiapan dalam memasuki pendidikan lebih lanjut (Imam Musbikin 2010:35).

Anak usia dinisering di jadikan topik pembahasan yang sangat luas dan semakin menarik. Karena usia prasekolah merupakan awal dari perkembangan anak. Hasil pengkajian dari anak prasekolah kian mengikat. Diharapkan dengan kesadaran terhadap anak didikyang semakin baik membawa hasil positif bagi pertumbuhan selanjutnya (Hibana S. Rahman, 2002:1).

\section{Kecerdasan Spiritual}

Yaitu bagian utama di kehidupan manusia. Dengan meningkatkan kecerdasan spiritual akan membuat manusia menjunjung tinggi nilai dan norma kehidupan. Kecerdasan spiritual juga yang akan menumbuhkan generasigenerasi yang berakhlakul karimah. Oleh karena itu, kecerdasan spiritual harus diutamakan sebagai pondasi kehidupan.

Agustian (2006) Kecerdasan spiritual ialah kemampuan untuk memberi makna kehidupan terhadap setiap tingkah laku dengan tahapan-tahapan dan pemikiran yang bersih, menuju kehidupan yang nyata serta memiliki daya pikir ketauhidan (integralistik) dan berprinsip kepada Allah.

Howard Gardner mendefenisikan kecerdasan spiritual sebagai sebuah perhatian bagi kehidupan yang sejati. Dia juga menyimpulkan dari kecerdasan ini yaitu untuk menempatkan diri dengan rasa hormat yang sebesar besarnya kepada sang Maha Pencipta yang tak terbatas dan tak terhingga dan berhubungan dengan kemampuan untuk menempatkan diri dengan rasa hormat serta kondisi manusia sebagai hal yang signifikan dalam kehidupan, arti dari kematian, takdir dan hal-hal seperti tidak mengaitkan kecerdasan spiritual ini dengan agama apapun.

Danah Johar dan ian Marshal mengemukakan bahwa kecerdasan jiwa ialah untuk menanggapi dan memecahkan masalah, menyimpan prilaku dan hidup manusia dalam berbagai makna yang lebih banyak dan kaya. Memberi nilai bahwa tindakan atau jalan hidup seseorang lebih bermakna di bandingkan dengan yang lainnya (Zohar dan Marshal, 2004).

\section{Metode}

\section{A. Jenis Penelitian}

Merupakan tindakan kelas, yaitu penelitian yang dimaksudkan untuk memperoleh informasi dari berbagai tindakan agar mampu meningkatkan kemampuan pendidik serta keaktifan siswa.

Penelitian ini dilaksanakan mulai tanggal 28 Desember 2017 sampai 8 Febuari 2018 pada semester genap tahun akademik 2017/2018 di RA AlbidayahCangkorahBatujajar dengan jenis pengkajian yaitu siswa-siswi kelas B RA Albidayah dengan jumlah anak didik 9 orang terdiri dari 4 anak laki-laki dan 5 perempuan.

\section{B. Indikator Kinerja}

Indikator kinerja dalam peningkatan kecerdasan spiritual yaitu:

Tingkat pemahaman serta pertumbuhanmasih relatif rendah pada kecerdasan spiritual di RA Albidayah Cangkorah Tahun Pelajaran 2017/2018 menjadikan alasan bagi peneliti 
memberikan target pencapaian mengikuti keadaan hasil belajar anak dalam satu kelas tersebut yaitu pembelajaran dengancararole playingyang hasilnya harus mampu memenuhi kriteria maksimum, yaitu nilai dalam kecerdasan spiritual dari target rata-rata $80 \%$, sehingga dapat dikatakan efektif untuk menambah kecerdasan spiritual, apabila:

1) Meningkatnya kecerdasan spiritual anaklebih dari $80 \%$.

2) Meningkatnya hasil belajar anak lebih dari $80 \%$.

3) Meningkatnyakeyakinan anak lebih dari $80 \%$.

4) Meningkatnya kecerdasan spiritual anak dari perolehanyang masih rendah.

\section{Analisis Data}

Ialah upaya atau metode pengolah data agar menjadi informasi, sehingga karakterikstik data bisa dimengerti serta bermanfaat bagi upaya permasalahan. Terutama permasalahan yang bersangkutan dengan penelitian atau definisi lain dari pengolahan data yaitu kegiatan yang dilakukan untuk mengubah hasil dari penelitian menjadi informasi, sehingga bisa dipergunakan dalam mengambil kesumpulan.

\section{Hasil}

Hasil dari evaluasi pada proses tindakan, peneliti telah melaksanakan tindakan penelitian yang serasi dengan desain pembelajaran yang sudah dirancang dan disesuaikan sebelumnya. Semua desain dilakukan dengan baik meskipun di awal penelitian masih terdapat beberapa kendala.Namun Alhamdulillah setelah dilaksanakannya siklus II terdapat perubahan sesuai dengan yang diharapkan.

Sesudah dilaksanakannya penelitian bermain peran, terdapat peningkatan nilai kecerdasan spiritual dari awal asesmen sampai akhir.Hasil perolehan data serta pembahasan, terjadi peningkatan kecerdasan spiritual anak setelah diberikan pembelajaran dengan menggunakan metode bermain peran.

\section{KESIMPULAN}

Dari hasil penelitian yang telah dilaksanakan, maka mampu diperoleh simpulan bahwa melalui cara bermain peran dapat meningkatkan kecerdasan spiritual anak di RA Albidayah. Dan ditandai dari ketercapaian indikator keberhasilan dari penganalisa dan adanya peningkatan kecerdasandi kondisi awal siklus I sampai siklus II. Di tandai oleh anak usia dini yang di awal penelitian masih kurang memahami bagaimana cara menjaga lingkungan yang bersih serta berdo'a di awal pelaksanaan pembelajaran masih jarang terlaksana, setelah adanya penelitian ke dua anak-anak mulai terbiasa melakukan kegiatan berdo'a di awal pembelajaran dan membuang sampah pada tempatnya.

\section{SARAN}

Dari hasil yang telah peneliti laksanakan selama melakukan observasi di RA Albidayah, peneliti memberikan saran sebagai berikut :

1. Bagi Anak yaitu, untuk menggunakan cararole playingdapat meningkatkan kecerdasan spiritual, dengan cara anak diberi berbagai macam metode serta anak diberi dorongan dan motivasi.

2. Bagi Guru, diharapkan guru lebih bisa berkreasi mengembangkan metode pembelajaran khususnya pembelajaran kecerdasan spiritual supaya anak mampu memperoleh kenyamanan.

3. Bagi Sekolah, disediakannya media pemebelajaranyang sesuai untuk anak-anak prasekolah, sehingga 
anak-anak mudah uuntuk menerima pembelajaran.

\section{DAFTAR PUSTAKA}

Agustian, A. 2006.ESQ Emotional Spiritual Quotient. Jakarta: Penerbit Arga

Hibana, S.Rahman (2002). Konsep Dasar pendidikan Anak Usia Dini. Yogyakarta :Galah.

HerdianaHeris\&Afriliato, M.2014. Panduan Bagi Guru Penelitian Tindakan Kelas Suatu Karya Tulis
Ilmiah.Bandung: PT

RedikaAditama

Gardner, Howard. 2003. Kecerdasan Majemuk (Multiple Intelligences) Teori dalam Praktek.Terjemahan oleh Alexander Sindoro.Batam: Interaksa.

Musbikin, Imam.2010: Guru yang menakjubkan. Jogjakarta: Buku Biru

UU RI Nomor 20 Tahun 2003, Tentang Sistem Pendidikan Nasional. Jakarta: CV Medya Jakarta. Musfiroh, Takdirotun. 2008. Cerdas Melalui Bermain. Jakarta: Grasind 